\title{
Sistem Informasi Korespondensi Rekam Medis di Rumah Sakit Menggunakan Microsoft Visual Studio
}

\author{
Rismaya Widia, Vini Novianti *, Yuda Syahidin, Meira Hidayati \\ Program Studi Informatika Rekam Medis \\ Politeknik Piksi Ganesha Bandung, Jawa Barat, Indonesia \\ piksi.rismaya.18403050@gmail.com, piksi.vini.18403048@gmail.com
}

\begin{abstract}
Technological developments in communication systems that are still used by humans. From traditional methods to using modern methods in accordance with current technological developments. One way to communicate using traditional methods that are still used today is by using letters. Medical record correspondence is an activity of correspondence related to patient medical record information in this case at the hospital, namely making letters to be treated, letters to request diagnosis, letters to carry out treatment, letters to finish treatment, and letters to death. Making letters, still manually using Microsoft Word. The process of making a certificate takes 1-2 days, so it is necessary to have an information system that can speed up the making of a certificate to be more efficient and effective. The design method uses the SDLC method. The stages of the method are planning (planning), analysis (analysis), design (design), implementation (implementation), and system maintenance (maintenance), the correspondence information system that has been created can be concluded that the system can facilitate officers in making certificates and can also speed up the creation of letters
\end{abstract}

Keywords: Information System, Correspondence, Medical Record, Hospital

ABSTRAK - Perkembangan teknologi pada sistem komunikasi yang masih terpakai oleh manusia. Dari metode yang tradisional hingga menggunakan metode yang modern yang sesuai dengan perkembangan teknologi saat ini. Salah satunya dengan cara berkomunikasi menggunakan metode tradisional yang masih dipakai pada saat ini adalah dengan menggunakan surat. Korespondensi rekam medis adalah suatu kegiatan dari surat menyurat yang berhubungan dengan informasi rekam medis pasien dalam hal ini di Rumah Sakit yaitu pembuatan surat untuk dirawat, surat untuk meminta diagnosa, surat untuk menjalankan pengobatan, surat untuk selesai pengobatan, dan surat untuk kematian. Pembuatan surat, masih secara manual dengan menggunakan Microsoft Word. Proses pembuatan surat keterangan memakan waktu 1-2 hari, sehingga diperlukan adanya sistem informasi yang dapat mempercepat pembuatan surat keterangan agar lebih efisien dan efektif. Metode perancangan menggunakan metode SDLC. Tahapan metode adalah perencanaan (planning), analisis (analysis), perancangan (design), implementasi (implementation), dan pemeliharaan sistem (maintenance), sistem informasi korespondensi yang telah dibuat ini dapat disimpulkan bahwa sistem tersebut dapat memudahkan petugas dalam pembuatan surat keterangan dan juga dapat mempercepat dalam pembuatan surat.

Kata Kunci: Sistem Informasi, Korespondensi, Rekam Medis, Rumah Sakit

\section{PENDAHULUAN}

Pelayanan kesehatan merupakan kewajiban untuk masyarakat yang dikembangkan berdasarkan tanggung jawab pemerintahan dalam melindungi masyarakat Indonesia dari berbagai penyakit maupun masalah kesehatan yang berkembang di indonesia. Oleh karena itu pemerintah telah mengadakan pelayanan kesehatan

Keputusan Menteri Kesehatan RI No 340/MENKES/PER/III/2010, rumah sakit adalah sebuah instansi pelayanan kesehatan yang menyelenggarakan kegiatan pelayanan kesehatan perorangan dengan cara paripurna dengan menyediakan kegiatan pelayanan untuk rawat inap, rawat jalan dan rawat darurat untuk menangani masalah kesehatan. Rumah sakit Khusus adalah rumah sakit yang menangani masalah kesehatan berdasarkan jenis penyakit tertentu, yaitu Rumah Sakit Khusus Paru (RSP) [1].

Rekam medis adalah catatan medis tentang bagaimana pemberian pelayanan kesehatan kepada pasien selama masa perawatan. Menurut PERMENKES nomor 269/MENKES/PER/3II/2008, rekam medis adalah suatu berkas yang berisikan catatan atau dokumen tentang identitas pasien, pemeriksaan, pengobatan, tindakan medis dan pelayanan lain yang telah diberikan kepada pasien. Petugas rekam medis melakukan proses pengolahan data rekam medis sehingga dapat menghasilkan informasi yang dapat digunakan sebagai bahan pelaporan rumah sakit dengan melalui proses pendaftaran pasien, merakit formulir berkas rekam medis (assembling) dan analisis kelengkapan berkas rekam medis rawat inap, rawat jalan, dan rawat darurat, pemberian kode penyakit (coding), tabulasi penyakit (indexing), pelaporan rumah sakit, korespondensi rekam medis, peng-input-an e-klaim BPJS koding casemix dan sistem penyimpanan (filling) [2].

Salah satu kegiatan rekam medis yang ada di Rumah Sakit, yaitu korespondensi rekam medis. Korespondensi merupakan suatu kegiatan surat menyurat yang berkaitan dengan informasi medis pasien contohnya surat dirawat, 
surat meminta diagnosa, surat menjalankan pengobatan, dan surat sudah selesai pengobatan, kegunaan Korespondensi rekam medis yaitu sebagai alat penghubung secara tertulis antara pasien atau keluarga pasien dengan rumah sakit, sebagai bahan dokumentasi untuk rumah sakit, dan sebagai wakil dari suatu instansi dalam hal ini adalah Fasilitas Kesehatan.

Teknologi komunikasi saat ini adalah suatu hal yang sangat penting didalam kehidupan manusia. Namun, manusia adalah individu sosial yang masih saling membutuhkan bantuan dari individu lainnya. Begitu pula, dengan individu yang berhubungan dengan individu lainnya dengan cara berkomunikasi. Seiring dengan berjalannya waktu, sistem komunikasi yang digunakan oleh manusia semakin berkembang. Salah satunya dengan cara berkomunikasi yang sejak dahulu masih dipakai hingga saat ini adalah dengan melakukan kegiatan surat- menyurat [3]. Dalam hal ini, kegiatan korespondensi rekam medis yang dilakukan di instalasi rekam medis Rumah Sakit yang ditemukan meliputi pembuatan surat keterangan untuk dirawat, surat keterangan untuk meminta diagnosa, surat keterangan untuk menjalankan pengobatan, surat keterangan sudah selesai pengobatan, dan surat keterangan untuk kematian. Pembuatan surat keterangan masih secara manual dengan menggunakan Microsoft Word. Proses pembuatan surat keterangan memakan waktu cukup lama sekitar 1-2 hari.

Dengan adanya teknologi yang berkembang dengan pesat, dalam penelitian ini diharapkan adanya sebuah sistem yang dapat membatu proses pembuatan surat keterangan di Rumah Sakit ini bisa lebih cepat dan efektif bagi petugas.

\section{METODOLOGI}

\section{A. Teknik Pengumpulan Data}

1) Observasi

Observasi adalah strategi atau teknik untuk mengumpulkan data atau informasi dengan melakukan pengamatan terhadap kegiatan secara terus menerus yang sedang berlangsung. Penelitian ini menggunakan observasi partisipasi. Dengan datang dan ikut berpartisipasi dalam kegiatan yang ada di instalasi rekam medis rumah sakit tersebut [4]. Penelitian ini melakukan pengamatan secara langsung dan mengambil bagian dalam kegiatan rekam medis yang ada di Rumah Sakit tersebut. Setiap harinya dengan konsisten. Dari hasil penelitian ini, ditemukan suatu masalah sehingga mendapatkan data maupun informasi yang sesuai kemudian dapat ditarik kesimpulan.

\section{2) Wawancara}

Menurut Sugiyono wawancara adalah proses pengumpulan data atau informasi yang dilakukan dengan cara terstruktur maupun tidak terstruktur dan bisa dilakukan secara langsung maupun dengan menggunakan media seperti jaringan telepon [5]. Penelitian ini melakukan wawancara dengan petugas rekam medis untuk mendapatkan data yang diperlukan, data tersebut berhubungan dengan pembuatan surat keterangan.

\section{3) Studi Pustaka}

Studi Pustaka adalah suatu metode pengumpulan informasi atau data dengan melakukan penelaahan bukubuku, literatur-literatur, catatan-catatan, karya tulis, dan laporan-laporan yang ada hubungannya dengan masalah yang akan dipecahkan [6]. Dalam penelitian ini, menggunakan referensi seperti jurnal-jurnal dan berbagai macam buku yang terkait dengan masalah penelitian. Dari proses ini, diharapkan dapat melengkapi informasi yang berguna untuk membantu dalam penyelesaian pemecahan masalah.

\section{B. Model Perancangan}

System Development Life Cycle (SDLC) adalah suatu metode umum yang digunakan untuk mengembangkan suatu sistem informasi. SDLC terdiri dari beberapa tahapan yaitu, mulai dari tahap perencanaan (planning), tahap analisis (analysis), tahap perancangan (design), tahap implementasi (implementation), dan tahap pemeliharaan sistem (maintenance) [7] seperti pada Gambar 1.

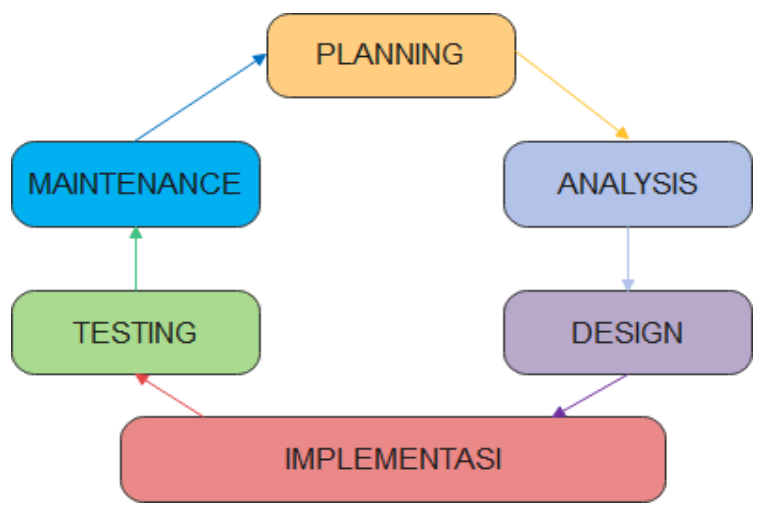

Gambar 1. Tahapan System Development Life Cycle (SDLC) 


\section{HASIL DAN PEMBAHASAN}

\section{A. Analisis Sistem Berjalan}

Pembuatan surat keterangan di Rumah Sakit ini masih secara manual, petugas pertama-tama akan menginput data pasien melalui formulir pengajuan pembuatan surat yang telah diisi pasien ke dalam format surat menggunakan Microsoft Word. Setelah petugas mengmasukkan data pasien kedalam format surat keterangan yang dibutuhkan, surat keterangan dicetak dan petugas akan langsung menghubungi pihak yang bersangkutan seperti direktur penunjang dan keperawatan di rumah sakit tersebut. Setelah surat keterangan selesai ditanda tangani, kemudian surat tersebut diberikan ke pasien atau keluarga pasien.

\section{B. Sistem yang akan Berjalan}

Sistem yang akan berjalan pada penelitian ini terdiri dari rancangan Flowmap, Diagram Korteks, Data Flow Diagram (DFD) Level 0, Entity Relationship Diagram (ERD), Database Specifications.
Gambar 2 memperlihatkan, Flowmap sistem yang akan berjalan. Flowmap sendiri adalah kombinasi antara peta dengan flowchart, yang menunjukan pergerakan alur benda dari satu area ke area lain, contohnya yaitu seperti jumlah individu yang dipindahkan, jumlah barang yang ditukarkan, atau jumlah paket dalam jaringan [8]. Penelitian ini menjelaskan flowmap sistem yang akan berjalan yaitu mulai dari pasien mengisi formulir pembuatan surat, lalu surat akan di proses melalui sistem yang sudah di buat dan ditanda tangani oleh pihak yangbersangkutan, setelah itu surat dibawa oleh pasien.

Berikutnya adalah Diagram Korteks. Diagram Korteks adalah suatu bagian level dari Data Flow Diagram (DFD) yang digunakan untuk menetapkan konteks serta batasan batasan pada suatu sistem yang ada pada sebuah pemodelan sistem yang dirancang [9]. Gambar 3 merupakan Diagram Korteks pada penelitian ini.

Data Flow Diagram atau DFD yaitu suatu teknik untuk membuat suatu kerangka sistem yang berorientasi pada alur data yang bergerak pada sebuah perancangan sistem lainya [10]. Dan Gambar 4 adalah DFD Level 0 pada sistem yang akan berjalan pada penelitian ini.

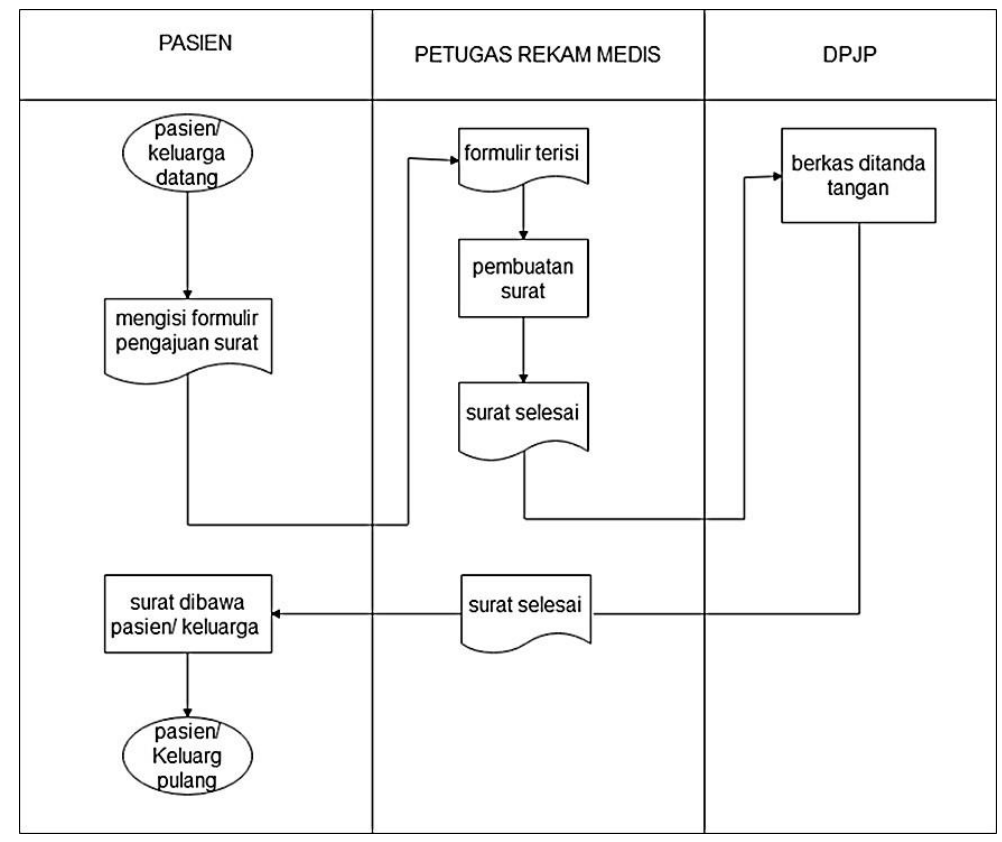

Gambar 2. Flowmap Sistem yang akan Berjalan

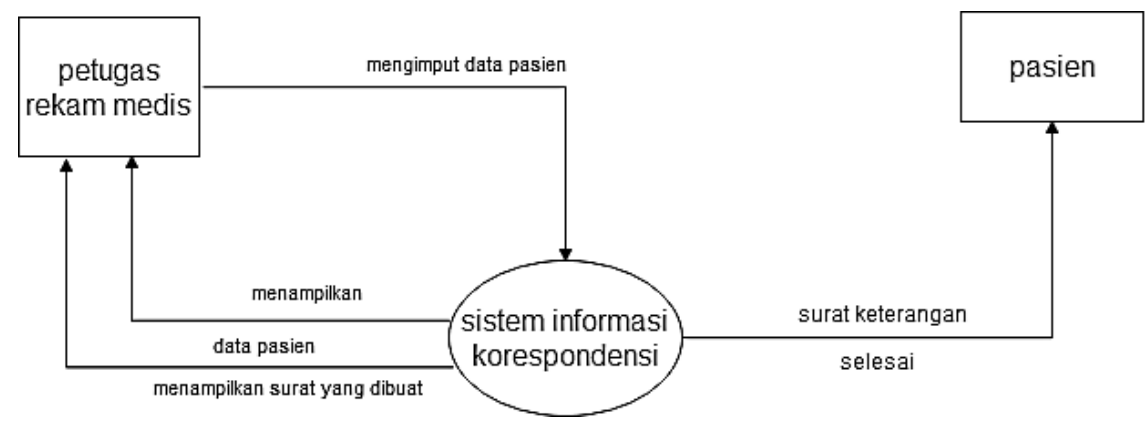

Gambar 3. Diagram Korteks Sistem yang akan Berjalan 


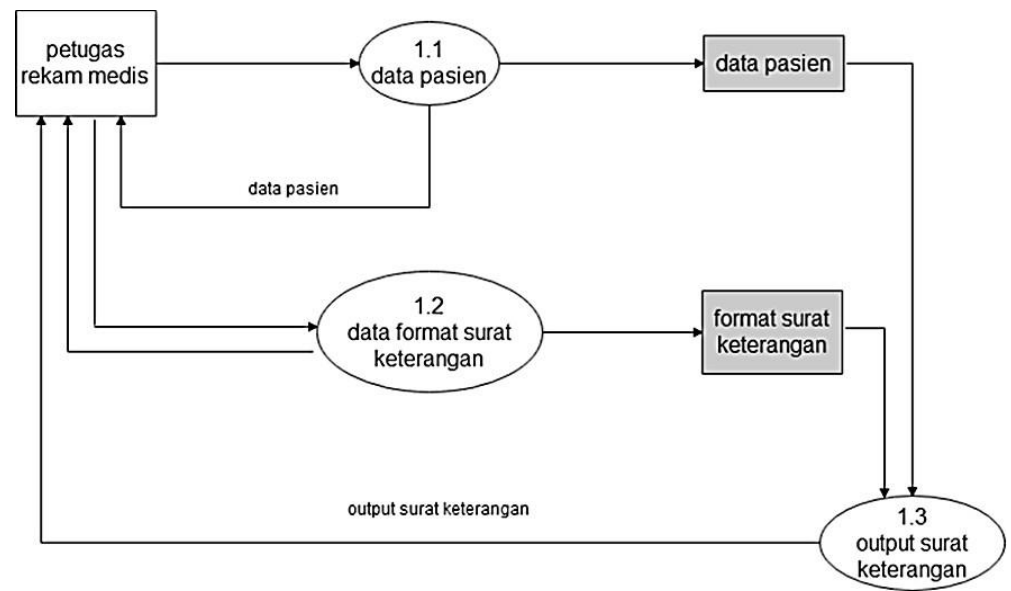

Gambar 4. Data Flow Diagram (DFD) Level 0 Sistem yang akan Berjalan

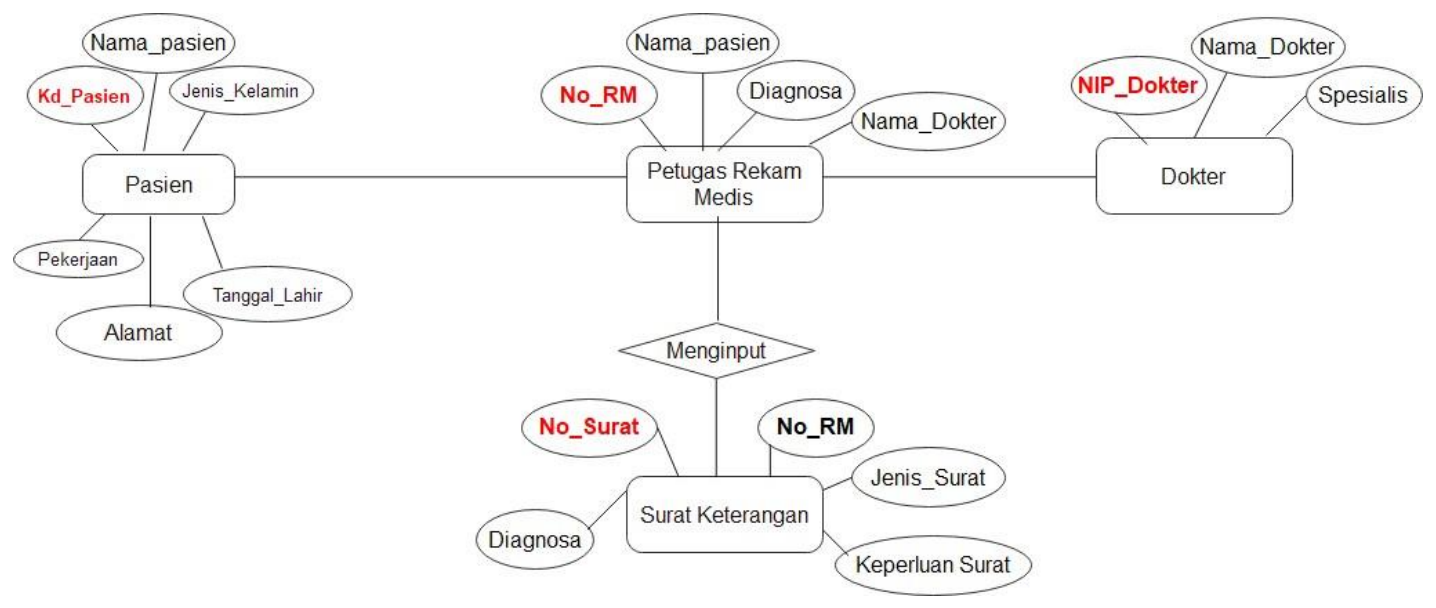

Gambar 5. Entity Relationship Diagram (ERD) Sistem yang akanBerjalan

Entity Relationship Diagram (ERD) adalah suatu teknikyang digunakan untuk memodelkan data dalam suatu kebutuhan data dari sebuah organisasi, biasanya digunakan untuk sistem analisis dalam tahap analisis ini merupakan suatu persyaratan proyek untuk pengembangan suatu sistem [10]. Dan Gambar 5 merupakan ERD sistem yang akan berjalan pada penelitian ini.

Berikutnya adalah tahapan Spesifikasi Basis Data (Database), Database adalah kumpulan data yang saling berelasi. Data sendiri merupakan fakta mengenai objek, orang, dan lain-lain. Menurut Sutarman, Database sekumpulan file yang saling berhubungan dan terorganisasi atau kumpulan record-record yang menyimpan data dan hubungan diantaranya [9]. Database yang digunakan dalam pembuatan sistem ini yaitu menggunakan Microsoft Access. Berikut adalah spesifikasi basis data pada sistem yang akan berjalan, terdiri dari 5 tabel yang digunakan dalam pembuatan database untuk sistem ini yaitu: Tabel User, Tabel Pasien,Tabel Dokter, Tabel Rekam Medis, dan Tabel Surat Keterangan.

1) Tabel User; merupakan tabel dalam database yang nantinya akan berfungsi untuk menyimpan data para pengguna sistem tersebut. Tabel 1 Nama tabel: tb_user, Isi: Data user, Primary key: Kd_user.

2) Tabel Pasien; merupakan tabel untuk pasien yang berfungsi untuk menyimpan data pasien yang berobat di Rumah Sakit. Tabel 2 Nama tabel: tb_pasien, Isi: Identitas pasien, Primary Key: Kd_Pasien.

Tabel 1. Spesifikasi Database Tabel User

\begin{tabular}{llll}
\hline Field & Type & Length & Keterangan \\
\hline Kd_User & Short Text & 10 & Kode petugas \\
Username & Short Text & 30 & Username petugas \\
Password & Short Text & 30 & Password petugas \\
Jabatan & Short Text & 20 & Jabatan petugas \\
\hline
\end{tabular}


3) Tabel Dokter; merupakan tabel untuk dokter yang bertugas yang berfungsi untuk menyimpan data dokter yang ada di Rumah Sakit. Tabel 3 Nama tabel: tb_dokter, Isi: Data dokter, Primary Key: NIP_dokter.

4) Tabel Rekam Medis; merupakan tabel yang berfungsi untuk menyimpan data nomor rekam medis pasien, beserta informasi medis pasien. Tabel 4 Nama tabel: rekam_medis, Isi: Informasi medis, Primary Key: No_RM.

5) Tabel Surat Keterangan; merupakan tabel pembuatan surat keterangan. Tabel ini berfungsi untuk menyimpan data pasien yang akan membuat suratketerangan. Tabel 5 Nama tabel: tb_Suket, Isi: Data surat keterangan, Primary Key: No_Surat.

Tabel 2. Spesifikasi Database Tabel Pasien

\begin{tabular}{llll}
\hline Field & Type & Length & Keterangan \\
\hline Kd_pasien & AutoNumber & 10 & Kode pasien \\
Nama & Short Text & 40 & Nama pasien \\
Jenis_klamin & Short Text & 5 & Jenis kelamin \\
Tanggal_lahir & Date/Time & 25 & Tanggal lahir \\
Alamat & Short Text & 20 & Alamat pasien \\
Pekerjaan & Short Text & 20 & Pekerjaan pasien \\
\hline
\end{tabular}

Tabel 3. Spesifikasi Database Tabel Dokter

\begin{tabular}{llll}
\hline Field & Type & Length & Keterangan \\
\hline NIP_dokter & Short Text & 10 & NIP dokter \\
Nama_dokter & Short Text & 30 & Nama dokter \\
Spesialis & Short Text & 30 & Spesialis \\
\hline
\end{tabular}

Tabel 4. Spesifikasi Database Tabel Rekam Medis

\begin{tabular}{llll}
\hline Field & Type & Length & Keterangan \\
\hline No RM & Short Text & 10 & Nomor rekam medis \\
Kd_pasien & AutoNumber & 10 & Kode pasien \\
Nama & Short Text & 30 & Nama pasien \\
NIP_Dokter & Short Text & 20 & NIP Dokter \\
Diagnosa & Short Text & 20 & Diagnosa \\
\hline
\end{tabular}

Tabel 5. Spesifikasi Database Tabel Surat Keterangan

\begin{tabular}{llll}
\hline Field & Type & Length & Keterangan \\
\hline No_Surat & Short Text & 20 & No surat \\
No_RM & Short Text & 10 & No rekam medis \\
Jenis_surat & Short Text & 30 & Jenis surat \\
Kebutuhan_surat & Short Text & 50 & Kebutuhan surat \\
\hline
\end{tabular}

\section{Implementasi Sistem}

Pembuatan perancangan suatu sistem yang kami buat program dengan menggunakan aplikasi Microsoft Visual Studio 2010 dengan menggunakan databse Microsoft Access program tersebut masih memiliki beberapa kekurangan, yaitu nomor Rekam Medis yang tidak bisa muncul secara otomatis, karena program ini belum terintegrasi dengan SIMRS yang sudah diterapkan di beberapa Rumah Sakit.

Gambar 6 merupakan halaman login, yang berfungsi untuk petugas yang akan menggunakan aplikasi dengan mamasukan username dan password yang ada pada sistem.

Gambar 7 merupakan halaman menu utamaberisikan halaman user, $\log$ out, halaman pasien, halaman dokter, halaman rekam medis, dan halaman surat keterangan, dan halaman laporan bulanan.
Gambar 8 merupakan halaman untuk pengguna user, berfungsi untuk memasukan data petugas yang belum bisa mengakses ke dalam aplikasi di Rumah Sakit tersebut.

Gambar 9 merupakan halaman untuk pasien yang berfungsi untuk mengisi data pasien oleh petugas di Rumah Sakit tersebut.

Gambar 10 merupakan halaman dokter berfungsi untuk petugas memasukan data dokter yang bertugas di Rumah Sakit tersebut.

Gambar 11 merupakan halaman surat ketarangan yang berfungsi untuk petugas memasukan nomor rekam medis pasien, lalu data pasien akan muncul secara otomatis dan petugas hanya akan memasukan jenis surat pasien dan keperluan surat yang akan dibuat. 


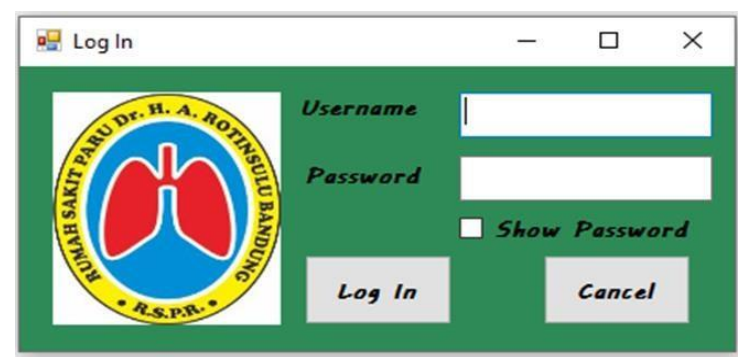

Gambar 6. Tampilan Form Log In

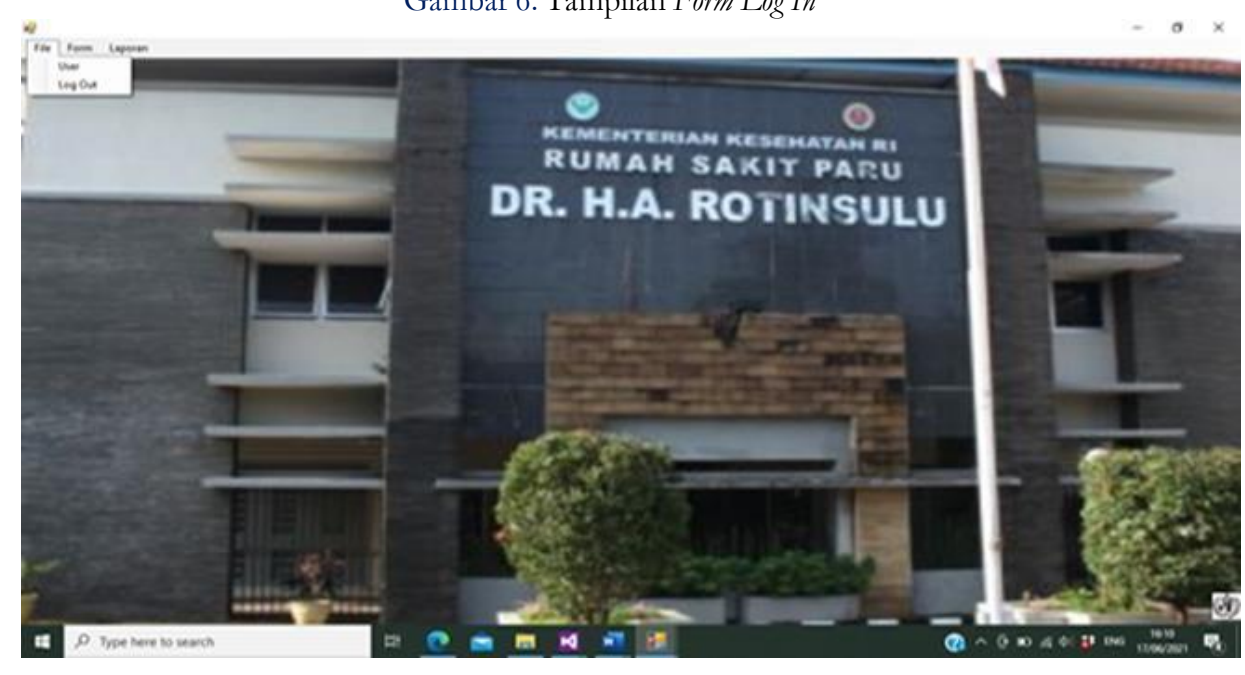

Gambar 7. Tampilan Form Menu Utama

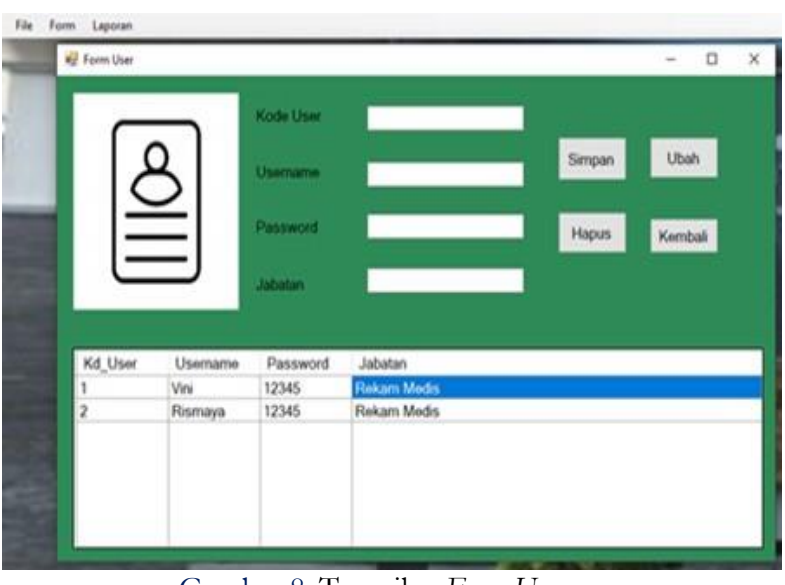

Gambar 8. Tampilan Form User

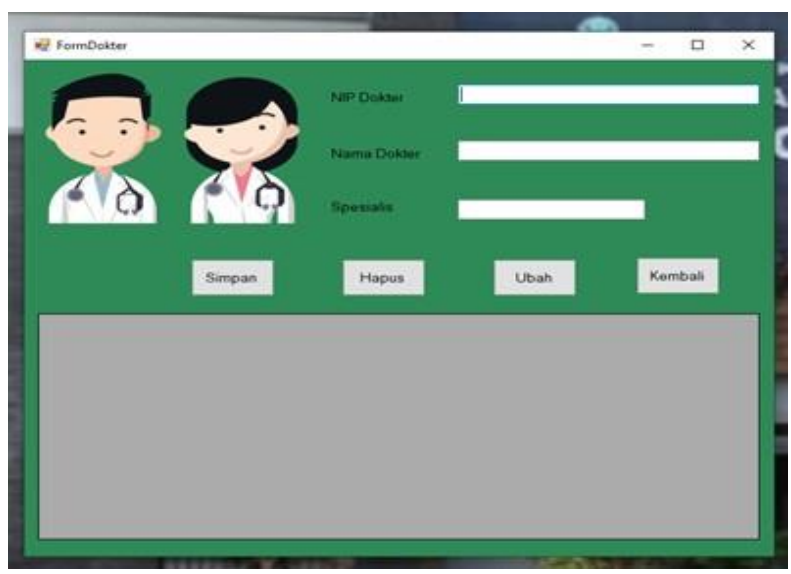

Gambar 10. Tampilan Form Dokter

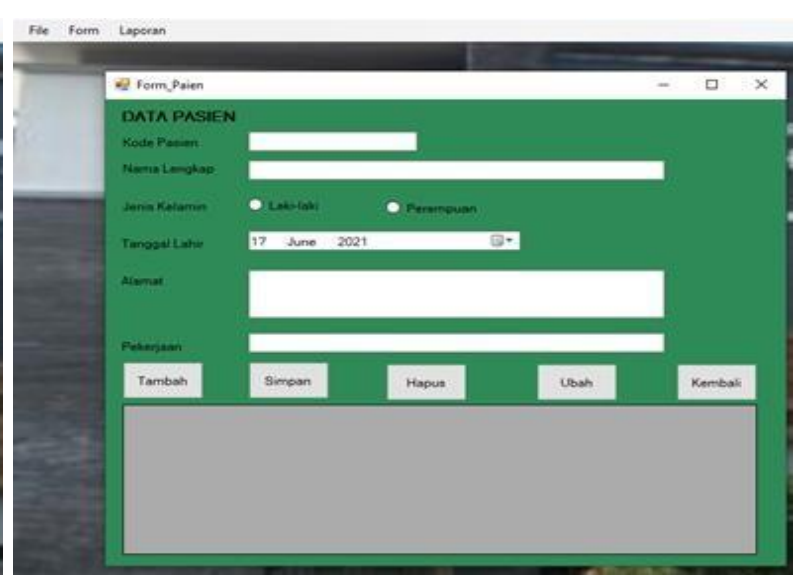

Gambar 9. Tampilan Form Pasien

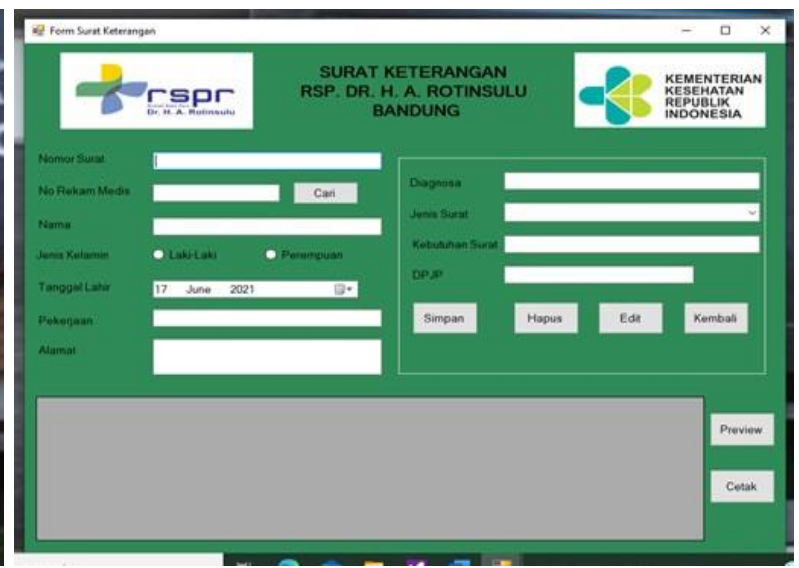

Gambar 11. Tampilan Form Surat Keterangan 


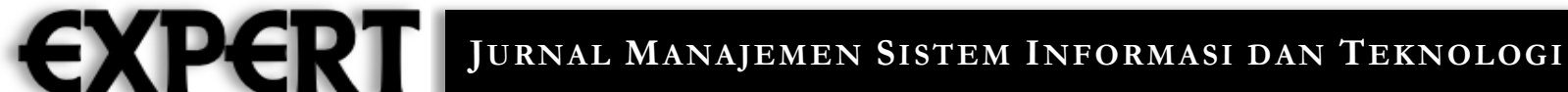

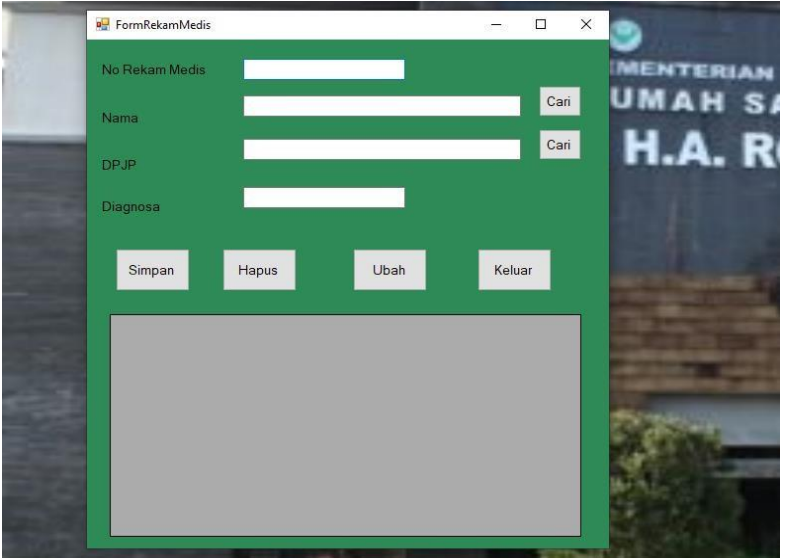

Gambar 12. Tampilan Form Rekam Medis

Gambar 12 merupakan halaman rekam medis yang berfungsi untuk petugas membuat nomor rekam medis pasien, karena aplikasi ini belum terintegrasi dengan SIMRS maka dibuatkan halaman untuk membuat nomor rekam medis pasien dengan cara mencari nama pasien, dokter yang bertanggung jawab dan memasukan diagnosa pasien, lalu data akan disimpan otomatis kedalam database yang sudah dibuat. Gambar 13 merupakan halaman laporan bulanan yang akan menampilkan

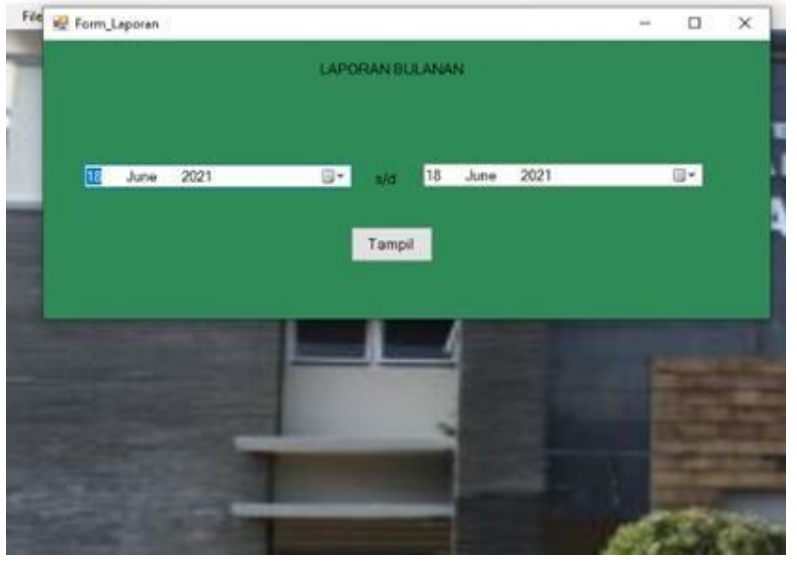

Gambar 13. Tampilan Form Laporan

laporan bulanan yang datanya sudah tersimpan didalam sistem menggunakan database.

Berikut ini merupakan contoh output yang dihasilkan dari program yang telah dibuat. Gambar 14 dibawah ini merupakan, hasil dari pembuatan surat keterangan kematian menggunakan aplikasi yang telah dibuat. Gambar 15 merupakan, tampilan dari laporan bulan Maret 2021 dengan menggunakan halaman laporan yang ada pada aplikasi tersebut.

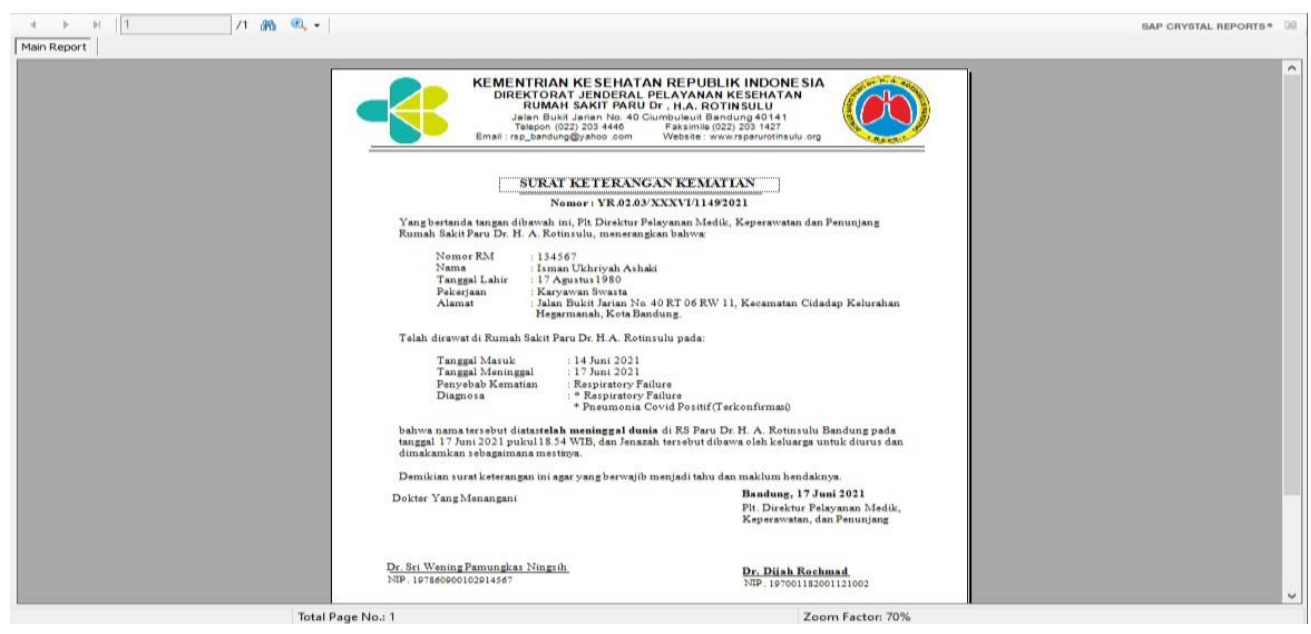

Gambar 13. Tampilan Form Cetak Surat Keterangan Kematian

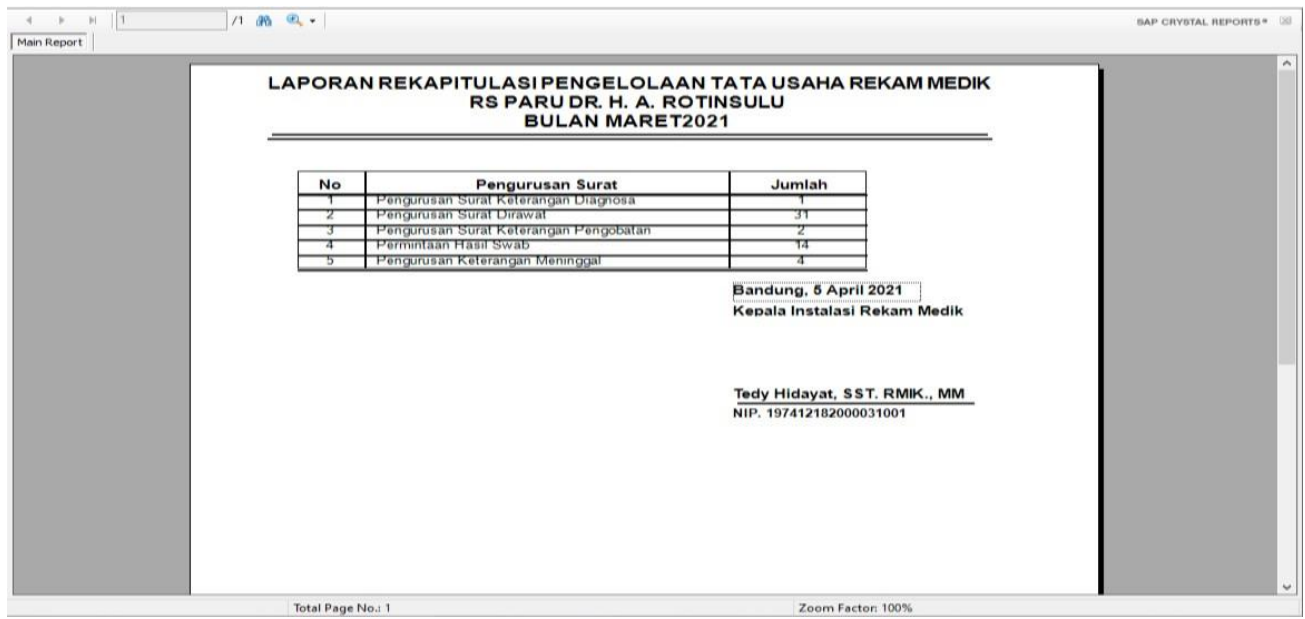

Gambar 13. Tampilan Cetak Laporan Bulanan 


\section{KESIMPULAN}

Sistem informasi korespondensi di rumah sakit tersebut, untuk pembuatan surat keterangan masih secara manual, dan penginputan data dilakukan dengan menggunakan Microsoft Word, hal ini menyebabkan petugas instalasi rekam medis harus menginput data pasien kedalam format pembuatan surat keterangan, dan dalam meminta tanda tangan, dokter penanggung jawab pasien, masih harus dengan menemui secara langsung dokter yang bersangkutan untuk meminta tanda tangan, sehingga belum bisa menghasilkan output Surat Keterangan secara cepat. Untuk itu perlu dibuatkannya suatu program korespondensi rekam medis, perancangan sistem ini diharapkan dapat membuat proses pembuatan surat keterangan menjadi efektif dan efisien.

\section{DAFTAR PUSTAKA}

[1] Republik Indonesia, "UU RI nomor 44 tahun 2009 tentang rumah sakit," Jakarta, 2009, doi: 10.1017/CBO9781107415324.004.

[2] Depkes RI, "Pedoman Penyelenggaraan dan Prosedur Rekam Medis Rumah Sakit di Indonesia.," J. Chem. Inf. Model., vol. 53, no. 9, 2010.
[3] E. Suharto, Pengantar Teknologi Informasi, 1st ed. Yogyakarta: penerbit ANDI, 2012.

[4] Zakky, "Pengertian Observasi Menurut Para Ahli dan Secara Umum [Lengkap]," www.zonareferensi. com, pp. 1-14, 2020, [Online]. Available: https://www.zonareferensi.com/pengertianobservasi/.

[5] M. Ilham, "Pengertian Wawancara Menurut Para Ahli," 22 Mei, 2019.

[6] J. Juhji, "Kepemimpinan: Sebuah Kajian Literatur," At-Tarbiyat J. Pendidik. Islam, vol. 3, no. 2, pp. 172186, 2020.

[7] Rosa and M. Shalahuddin, "Pengertian SDLC dan penerapannya," in Rekayasa perangkat lunak Terstruktur dan Berorientasi Objek, 2015.

[8] H. Jatnika, Sistem Informasi Manajemen Berbasis Komputer, 1st ed. Yogyakarta: penerbit ANDI, 2013.

[9] H. Jatnika, Pengantar Sistem Basis Data Memahami Konsep Dasar \& Tuntunan Praktis Perancangan Database, 1st ed. Yogyakarta: penerbit ANDI, 2013.

[10] S. K. Tata Sutabri, "Sistem Informasi Manajemen (edisi revisi)," CV. Andi Offset, 2016. 